Interdisciplinary Studies of Complex Systems

No. 14 (2019) 99-105

(C) T. Vlasova, L. Martseniuk

https://doi.org/10.31392/iscs.2019.14.099

\title{
INTERPRETIVE SUBJECTIVITY AND GENDER RELATIVISM IN THE THEORIES OF POSTMODERNISM
}

\author{
Tetyana Vlasova, Larysa Martseniuk ${ }^{1}$
}

\begin{abstract}
Interpretation as a stream of our consciousness is determined by different contexts and various narratives which stimulate this process reacting to the changeability of the world and human beings in it. The postmodern theory while losing its topicality keeps the key principle of interpretation firm and stable. Interpretation is simultaneously open and fixed, though the process of constructing narratives is not. As interpretation provides vast space for gender, the feminist theory proceeds with the "new feminist reading", and the aim of the feminist criticism lies in revealing misogynism and masculine approaches to different discourses and narratives. Still in postmodernism feminist interpretation often rejects "comprehension" in its classical meaning denying analogy, symmetry and equivalence. The subjectivity of feminist interpretation is not a transparent line between the human being and the surrounding world: the "better" is interpretation, the more "objective" seem our narratives, the stronger appear constructs stipulated by culture, gender, ideology.
\end{abstract}

Keywords: narrative, changeability, feminism, concept, translation, construct

\section{Introduction}

Nowadays scientists do not argue the statement that one of the main principles of the postmodern theory is its relativism. Researchers begin their discussions with noting the institutional assumption about representation of both the specific vision of the social reality and its specific epistemology. [5] Of great significance is also the fact that literature, in a broad meaning, has lost its importance as a depository of spiritual values of the human culture. These days the significance and appeal of literature are determined by the acceptance of the fact that all human activity is penetrated by "acts of interpretation". [7] Interpretation is considered to be simultaneously determined and open because the control over the development of the situation demands full realization of the reasons which stipulate our preference of the possibility of interpretation. On the other hand, narratives are not open but strictly fixed in our subconscious "Self". Narratives indicate what we are and what we can be in the world which is perceived by us. This process of constructing narratives is always enriched by "natural" interpretation, the latter accounts for the fact that this theme is in the focus of the interdisciplinary theories. Because interpretation

\footnotetext{
${ }^{1}$ Dnipro National University of Railway Transport named after Academician V. Lazaryan, Dnipro, Ukraine
} 
is "living our lives", we may paraphrase Descartes by saying: "We interpret therefore we live". [11] The latter is directly connected with the complications of the relativism, in general, and the concept of the narrative knowledge, in particular.

As one of the basic characteristics of postmodernism is the supposition that there is no "privileged knowledge", researchers proceed with the statement that there is no "true interpretation" which might deprive all the alternative versions of interpretation the right of being considered in the theory. It is interesting to mention how R. Rorty puts it: "Relativism is the view that every belief on a certain topic, or perhaps about any topic is as good as every other. [17] In postmodernity knowledge cannot be valued outside the context in its broad meaning, consequently there never exist universal out-of-context criteria of the truth and reliability.

In the outcome, postmodern critics consider relativism as the main threat to truth. [4]

Thus the main connection between postmodernism and relativism is reduced to the principle of truth as justified opinion. As a result, it is hermeneutics that has become the key to the postmodern transformations of such ultimate concepts as Truth, the Beauty, God. [4]

Those fundamental transformations, which are taking place in many axiological categories, turn the verge between the good and the evil, the virtue and the vice into some conventional notions (M. Foucault, J. Derrida, R.Rorty, S. Zizek,etc.). In today's pluralistic world there are no certainties; and without any fixed ideas can we still love the truth, - asks J. Caputo, who explores different notions of truth that we can interprete. Postmodernists are certain: relativism means that there is no "Truth", there are just a lot of "competing" truths depending on our language, culture, gender, religion, needs, tastes, etc. [4] In the criticism of postmodernism, the fear that relativism, skepticism, nihilism support anarchy is obvious, and many theorists admit that postmodern philosophers have done much to produce that impression. For example, R. Rorty once said that truth was merely a compliment we pay ourselves when things are going well with our beliefs. [17] "Are we just a collection of narratives?" ask scientists, who examine the "man" in his/her relation to the rest of reality. Postmodern researchers explore how today's rapid "movements" affect our understanding of ourselves. Starting their analysis with Descartes' claim that we are non-physical beings (even if it seems otherwise), and Locke's view that a person is self-conscious matter (though not necessarily in a human form), scientists depict how today's technology reconfigures our minds. [20]

Recently the feminist theory has not only opened the "sluice of silence" but changed the methodology of knowledge. In the context of "producing meanings" and their interpretations feminist researchers have set a problem of different perception of life by men and women as readers. Starting with S. de Beauvoir's statement that the woman is the eternal "Other" in the world of masculine discourses feminist philosophers have developed the theory of "critical revolution" - gynocriticism which was elaborated along with the French criticism (J. Kristeva, H. Cixous, L. Irigaray, etc.) and androgene poetics (M. Wittig, T. J. Atkinson, etc.) Gynocriticism having put women writers as a key research object simultaneously rejected the conception of a unique female essence and style (E. Showalter, J. Mitchell, S. Gilbert, etc.). In this connection 
scientists address $\mathrm{R}$. Barthes who in his books makes an accent on the interrelations of writing and the individuals. [3] It is worth while mentioning that feminist critics as a rule extol S. Freud for his acute observations concerning the psychological characteristics of women, at the same time Mitchell writes that both in their praises and attacks gender researchers often miss the fact that Freud analysed female psychology in the conception frame of patriarchy and physic diseases. [14]

On the whole, scientist claim that the research of women's literature along with the "female texts" has been the priority task of the feminist theory. It is considered an axiom that the "new reading" (i. e. interpretation) of different texts allows to escape traditional philosophic and socio-political interpretations of history and culture. R. Hof stresses that of great importance is the demand to understand that the interpretive history of sexes and their differentiation is in itself the part of the "social construction of reality" . [10]

As interpretations are not eternal and they are capable of change, explaining how such changes take place is one of the most important tasks of today's interpretation theory. The intention in this paper is to show that while basic human disposition makes interpretation appear to come naturally, the forms it takes - do not, and approaches to formulating forms of interpretation should be analysed and considered in their interconnection with objectivity and relativism.

\section{Drift from the vagueness of interpretation to the subjecti- vity of hermeneutics}

Nowadays the words "hermeneutics" and "interpretation" cover a wide variety of the theories of interpretation that should be focused on the analyses of the postmodern mutations of the basic philosophic concepts. As a rule interpretation seems to be a way of putting things under research in the definite focus in a certain framework. One of the main characteristic features of postmodernism is considered to be as follows: there are no "absolutes" without interpretation though interpretation does not create ultimate "Truth". Today it looks like interpretations are ever and everywhere in the "postmodern condition". The valid example can be provided with the notion of "Beauty". The beauty as an ultimate concept is recognized by "intuition", but between the physical beauty and the spiritual one the gap can be installed, and simultaneously the problem of the taste arises, - the taste as the power of the design over the consciousness, as the capability to follow the demands of the vogue. In the outcome, the whole $\mathrm{XX}^{t h}$ century is marked by breaking the superiority of the beautiful over the ugly; nowadays, as F. Girenock puts it, the "ugly" exists "by itself", the "beautiful" also exists "by itself", and they have become equal. [9]

It should be stressed that the problem of interpretation in hermeneutics was stipulated by R. Barthes' "The Death of the Author", by putting the text and its meanings precisely under the postmodern conditions in which interpretations are inevitable because writing tends to a "zero degree of meaning". Thus, texts that readers use are evershifting, unstable and open to questions. R. Barthes notes that the traditional critical approach rises the following pro- 
blem: how can we detect precisely what the author's intention is? The author is merely a "scriptor" — the word, that Barthes uses to disrupt the traditional continuity between the terms "author" and "authority". The scriptor exists to produce but not to explain his/her work, - underlines R. Barthes, and "The Death of the Author" develops a reader's response critical theory, which encourages readers for interpreting any text. Postmodernists assume textuality to be a moveable "woven tapestry", and it is intertextuality that weaves tapestries of individual texts together. The text does not belong to anyone, the text is simply there, waiting for someone to make a meaning, - the idea that acknowledges the fluid function of textuality and the ever openness for interpretation.

In "Mythologies" R. Barthes claims that everything or anything in culture can be decoded, not just literature, but love, fashion, photography, etc. For Barthes, words and objects have in common the organized capacity to say something at the same time, since they are signs; words and objects have the ability to appear natural, as if what they say were eternal and true instead of arbitrary and opinionated. [1]

Here R. Barthes is of great importance because he is an exponent of the semiotic model of language, which U. Eco calls "the natural language". As U. Eco puts it, any natural language consists of the plane of expression (lexis, phonology and syntax), and the plane of meaning which represents the complex of the notions that can be expressed. Any language organizes "universum" that can be thought and told about in a definite form of the content. Thus, the natural language is defined by U. Eco as a holistic system; though it is structured in a definite way, and proposes a definite vision of the world. [7]

And here arises the problem of denotation and signification. In structuralism, meaning is the product of a system of representation which in itself is meaningless. The latter is inevitably connected with the problem of translation: U. Eco claims, that as a result of its lasting search the European culture has put itself confronted with the urgent necessity to find the "language-mediator" which could bind the "linguistic breakings". The fact that the problem of translation concerns a "perfect" language is known to be mentioned by W. Benjamin, who wrote that because it was impossible to reproduce precisely the meaning of the source text in the target language, it was necessary to rely on the feeling of coincidence among the languages. The theoretical complexity of the problem was touched upon by F. W. Humboldt, who claimed that if no word of another language had an equivalent, translation was impossible but for the case of understanding translation as an activity which did not yield to regulation and formalization. [7]

The significance of the interpreter is always great when we deal with translation: because there is no perfect equivalence between the units of the codes, we can speak only about the adequacy of the messages. A translator does not substitute code units but change messages, thus a translator acts as an interpreter - encoding and decoding messages received from a source text. U. Eco proposes to think not of "a third language parameter" in translation but of an instrument of comparison. Presumably, in this case we speak about a metalanguage as a technical language; e.g., structuralism, which was devised to describe the properties of an ordinary language. Structuralists (F. de Saussure, C. Levi-Strauss and others) promised "liberation from the enigma of 
meaning", but in the outcome, they came back to the language. It is important that P. Ricoeur demonstrates a complicated attitude to structuralism: he does not recognize it as philosophic discipline; to him, structuralism is science while hermeneutics is a philosophic discipline. Hermeneutics, according to P. Ricoeur, means finding out the meaning hidden in a symbol, and in this very meaning hermeneutics is philosophy.

However, proceeds P. Ricoeur, in every hermeneutic discipline interpretation is at the core of the linguistic/ non- linguistic language and life experience. [16] Specific features of hermeneutics are represented in the fact that the impact of the language on the individual, and of the individual on the language is realized by different ways. Here of great significance is a moment that multiple "vaguenesses", which lead to the distortion of the communication product, inevitably occur. As for the cultural communication in the literary criticism the term "resistance of the literary work to reading" is supposed to denote peculiarities of the language functioning in fiction.

\section{From narrative individuation to gender relativism}

Analysing reading in the way of deconstruction J. Miller claims that "resistance of the literary work to reading" is a property of words of the literary work, a property of rhetoric, results of interaction, games of tropes, concepts, narratives. It is an impression that a work of art produces on readers by means of the sequence of words",- - J. Miller asserts not without the influence of the phenomenological school, closely connected with hermeneutics. [15] The paradox is as follows: the text makes a reader believe that he/she can determine the meaning of the text and simultaneously makes it impossible, which should not be mixed with understanding multiple meanings as ambiguity. On the other hand, it differs from the approach according to which every reader adds his/her own meanings to the text, and that is why any text acquires different meanings for different readers. However, readers - and writers as well - often yield in their estimations to dwell on the one general meaning in their necessity to rely on the faith concerning a piece of art. To Miller, it resembles the property of Mobius strip that simultaneously possesses both the one and the two surfaces.

Here we should recollect that J. Derrida mobilizes the radical poststructuralist implications of the point that structures of meaning include any observers of them: to observe is to interact, claims J. Derrida. [6] It is necessary to mention that in every hermeneutic discipline interpretation is located at the junction of the linguistic and the non-linguistic, the language and the life experience. [16] The crucial point is "the frame" constructed by both; (i.e. "the context"). Nothing can be understood without a set of presuppositions within which things are properly or improperly framed. [16] Still subjectivity is a kind of borderline between an individual and the reality, everyone and all are socially and ideologically constructed.

The fact that literature happened to be in the centre of the second wave of feminism in the 60 s of the last century was not by accident. The literary discourse was one of the few by means of which it was possible to reconstruct the socio-cultural reality of women. Exposing negative women's images in the novels of H. Miller, D.H. Lawrence, H. Mailer, L. Tolstoy and other writers, 
K. Millett, A. Dworkin, A. Rich, T. Moi and other researchers proposed the problem of the connection of femininity and its representation in the "masculine literature" and focused on it in their analysis of the feminine aesthetics, poetics, gynocriticism. Acknowledging that women have been "captives" of the masculine texts for centuries, feminist critics propose strategies which can help to avoid the captivity of the masculine literature: for instance, it is a strategy of the "resisting reader" (J. Feterly) or "new ways of reading" which on purpose cross the line of the "generic text", because not to perform the extending reading means to be "inside" the canon. Thus "reading-interpretation" has become an issue of power, a "critical stake" in the development of the feminist "reader-centered" theory.

Feminist interpretation of texts has been aimed at revealing gender inequality, and the latter is vividly represented in J. Lorber's conception: she analyses thirteen evolutions of the theory of gender inequality structured around the author's paradigm "reforming - resistence - riot" in different combinations of the structure "text-reader". [13] On the other hand, A. Kolodny assumes that pluralism and feminism can sound antagonistic, because pluralism lies in what G. Spivak calls "ideology of free entreprenership in action"; though A. Kolodny offers to adopt a phrase "playful pluralism". [12] One of the main terms which is used by postmodernists is "life experience" and up to the 70s of the last century women's life experience had been considered physiological and secondary. Postmodernism in its deconstruction of the notion of "subject" destroys traditional dichotomies and consequently oppositional thinking on the whole. Still it is significant to stress: the issue of the validity of the women's experience has been very problematic in the postmodern anthropology. [19]

All mentioned above is reflected in the feminist interpretive reading of various texts. As for fiction, it seems D.H. Lawrence "suffered" most of all: only very apathetic feminists have not attacked his "Lady Chatterley's Lover", "Sons and Lovers", "The Rainbow" and other novels. The next layer of feminist interpretation is the "new reading" of S. Freud and other researchers of psychoanalysis. An interesting example is feminist interpretation of W. James' fatherfounder of the American psychology, his studies have been interpreted in the context of ethics and epistemology. [18] Concerning philosophical studies, it should be noted that all the periods of the Western philosophical thought have been analysed in the feminist interpretation (M. L. Shanley, C. Pateman, M. Batler, N. Frazer, E. Spelman, S. Okin, N. Chukhim, T. Vlasova, etc.)

\section{Conclusions}

In the postmodern theories there has established a tendency to interprete ultimate concepts as "symbols of change": the ambiguity of their meanings, the localized context, and the decentred life in the story-telling of narratives and histories.

In our postmodern movement away from the "Absolutes" we are approaching a "zero" point now. The problem also lies in the necessity to find the "language mediator" - not a "perfect language" (U. Eco) but a perfect work of an interpreter in the broad meaning of this word. The feminist interpretation of various texts during the last years provides a good testimony to this 
supposition, at the same time it is important to stress that the work of an interpreter always means "crossing the line", - the line that is not transparent between the man and the reality of the world. However, the paradox lies in the fact that the "better" is interpretation, the more "objective" seem narratives, and the stronger become constructs stipulated by history, culture, gender, and ideology.

\section{References}

[1] Barthes, R. 1972. Mythologies. Straus and Giroux, Farrar, 160 p.

[2] Barthes, R. 1983. A Barthes Reader. Hill and Wang, 534 p.

[3] Barthes, R. 2008. Writing degree zero. Academic Project, 431 p.

[4] Caputo, J.D. 2013. Truth. Philosophy in Transit. Penguin Press, 284 p.

[5] Caputo, J.D. 2015. Hoping against Hope. Fortress Press, 226 p.

[6] Derrida, J. 2007. Positions. Academic Project, 160 p.

[7] Eco, U. 2009. The Search for the Perfect Language. The Making of Europe, Alexandria, $423 \mathrm{p}$.

[8] Eco, U. 1992. Interpretation and Overinterpretation. Cambridge University Press, $164 \mathrm{p}$.

[9] Girenock, F. 2010. The pleasure of the different thinking. Academic Project, $235 \mathrm{p}$.

[10] Renate, H. 2009. The emergence and development of gender studies. In: Gender. Gender Culture: German and Russian Studies, 31-60.

[11] Iser, W. 2001. The Range of Interpretation. Columbia University Press, 280 p.

[12] Kolodny, A. 1986. A map for rereading: Or, Gender and Interpretation of Literary Texts. New Literary History. 11(3):451-467.

[13] Lorber, J. 2011. Gender Equality: Feminist Theories and Politics. Oxford University Press, 354 p.

[14] Mitchell, J. 2004. The holy family family. In: Psychoanalysis and Feminism, Flinta, 156-191.

[15] Miller, J. 2004. The pattern of the carpet. Contemporary literary theory, 92-109.

[16] Ricoeur, P. 2008. The conflict of Interpretations: Essays in Hermeneutics. Academic Project, 695 p.

[17] Rorty Richard, Consequences of Pragmatism (University of Minnesota Press, 1982), $237 \mathrm{p}$.

[18] Smith, P.J. 2017. The soul of Woman: An interpretation of the Philosophy of Feminism. Forgotten Books, 84 p.

[19] Vlasova, T., I. Grabovska and J. Galitska. 2018. Topical Gender: International and Ukrainian contexts. Millenium, $135 \mathrm{p}$.

[20] Zizek, S. 2018. Like a Thief in Broad Daylight. Power in the Era of Posthumanity. Allen Lane, $240 \mathrm{p}$.

[21] Zizek, S. 2015. Trouble in Paradise: From the End of History in the End of Capitalism. Penguin Books, 208 p. 